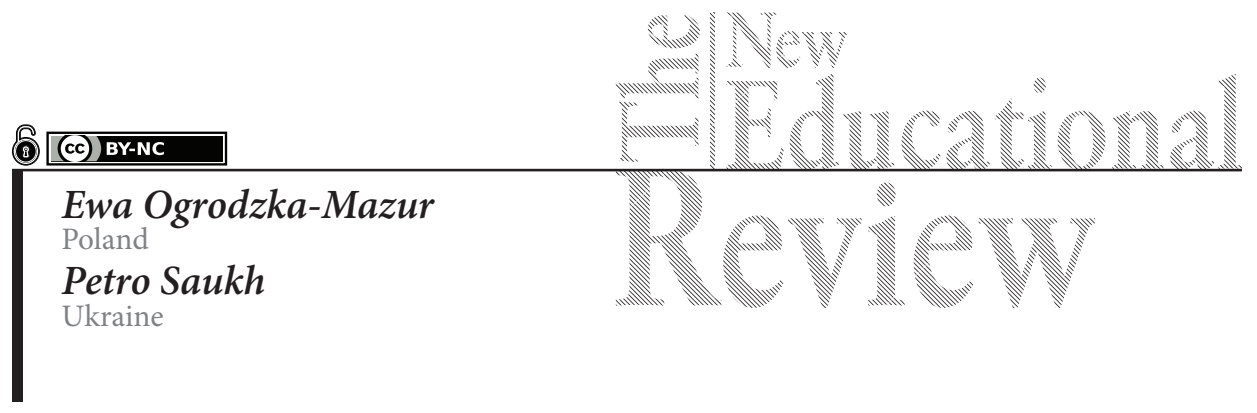

\title{
Contemporary Polish and Ukrainian Academic Youth: A Portrait Without Ornaments. A comparative Analysis
}

DOI: 10.15804/tner.2020.62.4.01

\begin{abstract}
In the philosophical-pedagogical analysis of the undertaken issues, some theoretical and methodological conceptualizations have been applied that refer to Paweł Boski's theory of the cultural identity based on values and practices in bi-or multicultural socialization and Harold J. Noah's model of the comparison of academic education. The assumption was also made that the research into the quality of life of Polish and Ukrainian university students enables one to learn the way(s) in which students understand themselves, the others and the world - the way(s) anchored in their own experience and culture.

The undertaken studies also address the important problem of forming students' identity in the stage of the so called emerging adulthood. It occurs in the countries where a knowledge-based economy dominates and where the intensive changes both decrease the young's motivation to engage in adult roles and make the young postpone them.
\end{abstract}

Key words: identity forming in early adulthood, axiological preferences, one's own life situation, Polish and Ukrainian academic youth, comparative study 


\section{Introduction: Emerging adulthood - identity forming in the period of early adulthood}

Without a doubt, contemporary academic youth, who live in a complicated and contradicting reality, must answer some crucial existential questions: Who am I? Where do I belong? Who can I be? This social group is in a special situation, as it is subjected to various socializing experiments of history, it experiences the phenomena of exclusion, freedom, disintegration and integration of identity. The identities and biographies of the young are shaped by macro-social and macro-economic tendencies.

The most recent psychological studies on the process of undertaking adult social roles and on the development of personality have been largely influenced by Jensen Arnett's theory of emerging adulthood, which was put forward nearly two decades ago. The stage of emerging adulthood occurs in the countries in which the knowledge-based economy dominates and in which the people aiming at satisfying social positions have to devote many years to gain education and experience and - therefore - they postpone adulthood tasks until they acquire an appropriate (in their opinion) social and professional position (Arnett, 2000, pp. 470-479). Such a situation takes place in Poland and Ukraine, where many young people aged 18-30 (especially until 25) complete the consecutive levels of education (after graduating from secondary school) and collect their first experiences at work. This will bring effects not earlier than in later years.

The cases of Poland and Ukraine point to the occurrence of similar social transformations which result in putting off the moment of entering into adulthood and in prolonging the time for shaping the basic competences, such as responsibility for one's own acts, the acquisition of autonomy, or building one's own - open, flexible, but at the same time clear and stable - identity. In contrast to the beginning of the transformation period in the 1990s, currently - the number of Polish and Ukrainian young adults who continue education at university has increased three times and constitutes $50 \%$ of the whole population at the age 19-24 (Report, 2014; Laird, Harvey, Lancaster, 2015, pp. 87-100; European Commission, 2018).

\section{Theoretical and methodological assumptions of the research}

In the pedagogical analysis of the undertaken issues concerning the cultural identity and education of young adults learning in a culturally diversified environment, some theoretical conceptualizations were applied related to Paweł Boski’s 
(1) theory of cultural identity based on values and practices in the conditions of bi- and multicultural socialization. Reaching for the suggested model in pedagogical analyses assumes the possibility of cultural transmission in the conditions of an intentional learning process (i.e. in the family, school, peer group, local environment) and some experiences in the social discourse of a particular country (Boski, 2009, pp. 548-564).

In the undertaken research, the (2) constructivist perspective was also applied, which consisted in emphasizing learners' activeness in the educational process and the resulting construction of their own educational reality (Bruner, 1996; Lunenburg, 1998, pp. 75-81). This approach seems particularly useful in the interpretation of university students' learning, which is understood as participation in constructing the social world and a common culture.

Due to the comparative character of the research, some references were made to Harold J. Noah's (3) model of qualitative comparison of academic education (Noah, Eckstein 1988, pp. 165-192; Marshall, 2014). This referred to the case of Poland and Ukraine and took into account a description of the traditions and latest tendencies in higher education in both countries, namely, an analysis of university curricula, socio-economic and cultural contexts, as well as some interpretations of the educational phenomena which might become change predictors

Own research was carried out in culturally diverse environments of Poland and Ukraine. In accordance with the applied methodological standpoint, the research was conducted with the use of both quantitative and qualitative methods and particular research tools, elaborated on the basis of the research procedures recognized within these methods. Their choice and/or construction (in the case of the authors' tools) were determined by the applied theories and the research assumptions resulting from them ${ }^{1}$.

\section{One's own life situation of Polish students and satisfaction from it versus the feeling of identity}

Young adults' assessment of their own life situation is related to such cognitive categories as satisfaction, happiness, feeling of mental welfare, satisfaction with life

1 The own research conducted in 2017-2018 and in 2019-2020 comprised 378 Polish B.A. and M.A. pedagogy students from the University of Silesia in Katowice (Faculty of Arts and Educational Science). The required representative sample size was specified with the help of the sample size calculator. For the size of population, the following was assumed: fraction size 0.5 , confidence interval $85 \%$, maximum error 0.5 . 
or with its quality. As many psychologists and researchers into this subject emphasize, these terms are not identical, yet - they all refer to the individual's general attitude to life, owing to which a person actively struggles against adversities and consistently aims at fulfilling important values (Malinauskas, Dumciene, Lapeniene, 2014, pp. 285-293; Riberio, Pereira, Freire, Oliveira, Casotii, Boery, 2018, pp. 70-77).

The surveyed academic youth expressed their opinions on a 1-7 scale - from extreme, severe and moderate dissatisfaction, through moderate, severe and extreme satisfaction, to the answer "this does not concern me". The declarations composed four characteristic subsystems.

What is located in the first subsystem are the indications concerning the fields of life with which the academic youth is satisfied - family life (96\%), the environment of friends (91\%) and the own health (88\%). The respondents express lesser satisfaction at life and educational achievements $(86 \%)$, ways of spending leisure time (85\%), studies (84\%) and emotional life (82\%). They are much less satisfied also with their current financial situation $(76 \%)$ and professional prospects after their studies $(70 \%)$. The fourth subsystem is composed of the fields with which the respondents are the least satisfied - the economic (50\%) and political (36\%) situation in Poland.

The subjective evaluation of their own life situation and satisfaction with it, as outlined by Polish students, is determined by the individual system of their values and it indicates the way of students' perceiving the surrounding reality. As the analyses carried out so far show, young adult learners give the highest rank in their life to family values and to the peer environment (including friends and acquaintances). They are also satisfied with their health condition and they undertake various activities (e.g. regular sport exercises, healthy nutrition, healthy lifestyle) which confirm their pro-health attitudes. It does not seem to be a surprise that the respondents are not satisfied with the economic and political situation in their countries, which in fact determines their financial status, educational possibilities and professional prospects after their studies.

In the authorial studies, an attempt was also made to specify the relationship between Polish students' life satisfaction and their feeling of identity in the local, regional, national, European and supra-European dimension. The detailed data concerning the statistically significant relationships are presented in Table 1.

In the environment of academic youth, the people who feel significantly more strongly associated with their living place are simultaneously very satisfied with their studies (Mann-Whitney $U$ test: $Z=2.65 ; p=0.008)$, family life $(Z=2.35$; $p$ $=0.02)$ and friends $(Z=2.20 ; p=0.03)$. Yet, they critically evaluate their town or 
village as regards the economic and political situation of the country $(Z=-2.45$; $\mathrm{p}=0.04)$, professional prospects after their studies $(Z=-2.19 ; \mathrm{p}=0.029)$, the possibilities of spending leisure time $(Z=-2.03 ; p=0.042)$ and their own health condition $(\mathrm{Z}=-2.01 ; \mathrm{p}=0.044)$.

The significantly strong association with the region is related to students' satisfaction with friends $(Z=2.97 ; p=0.003)$, studies $(Z=2.76 ; p=0.006)$, professional prospects after studies $(\mathrm{Z}=2.54 ; \mathrm{p}=0.011)$ and family life $(\mathrm{Z}=2.22 ; \mathrm{p}=0.03)$.

Young adults assess their feeling of being a citizen of Poland through negative experiences and dissatisfaction at the economic situation of the state $(Z=-2.34 ; p$ $=0.019)$, professional prospects after their studies $(Z=-2.40 ; \mathrm{p}=0.017)$ and their own emotional life $(Z=-2.03 ; p=0.04)$. Only the students who are satisfied with their family life are at the same time more strongly emotionally attached to their homeland $(Z=2.03 ; \mathrm{p}=0.04)$.

Table 1. Evaluation of Polish students' satisfaction versus their feeling of identity (statistically significant data)

\begin{tabular}{|c|c|c|c|c|c|c|}
\hline Categories & & $\begin{array}{c}\text { I feel } \\
\text { a resident of } \\
\text { my town / } \\
\text { village }\end{array}$ & $\begin{array}{l}\text { I feel } \\
\text { a resident of } \\
\text { the region }\end{array}$ & $\begin{array}{l}\text { I feel } \\
\text { a citizen of } \\
\text { Poland }\end{array}$ & $\begin{array}{c}\text { I feel } \\
\text { a European }\end{array}$ & $\begin{array}{l}\text { I feel a cit- } \\
\text { izen of the } \\
\text { world }\end{array}$ \\
\hline \multirow[t]{2}{*}{ Family life } & $\mathrm{S}$ & $\mathrm{H}$ & $\mathrm{H}$ & $\mathrm{H}$ & $\mathrm{H}$ & $\mathrm{H}$ \\
\hline & NS & & & & & \\
\hline \multirow[t]{2}{*}{ Emotional life } & $\mathrm{S}$ & & & & $\mathrm{H}$ & $\mathrm{H}$ \\
\hline & NS & & & $\mathrm{L}$ & & \\
\hline \multirow{2}{*}{$\begin{array}{l}\text { Financial } \\
\text { situation }\end{array}$} & $\mathrm{S}$ & & & & & \\
\hline & NS & & & & & \\
\hline \multirow{2}{*}{$\begin{array}{l}\text { Health condi- } \\
\text { tion }\end{array}$} & $\mathrm{S}$ & & & & & \\
\hline & NS & $\mathrm{L}$ & $\mathrm{L}$ & & & \\
\hline \multirow[t]{2}{*}{ Studies } & $\mathrm{S}$ & $\mathrm{H}$ & $\mathrm{H}$ & & & \\
\hline & NS & & $\mathrm{L}$ & & & \\
\hline \multirow[t]{2}{*}{ Friends } & $\mathrm{S}$ & $\mathrm{H}$ & $\mathrm{H}$ & & $\mathrm{H}$ & \\
\hline & NS & & $\mathrm{H}$ & & & \\
\hline \multirow{2}{*}{$\begin{array}{l}\text { Ways of } \\
\text { spending free } \\
\text { time }\end{array}$} & $\mathrm{S}$ & $\mathrm{L}$ & & & & \\
\hline & NS & & & & & \\
\hline \multirow{2}{*}{$\begin{array}{l}\text { Students' own } \\
\text { life and educa- } \\
\text { tional achieve- } \\
\text { ments }\end{array}$} & $\mathrm{S}$ & & & & & \\
\hline & NS & & & & & \\
\hline
\end{tabular}




\begin{tabular}{|c|c|c|c|c|c|c|}
\hline \multicolumn{2}{|l|}{ Categories } & $\begin{array}{c}\text { I feel } \\
\text { a resident of } \\
\text { my town / } \\
\text { village }\end{array}$ & $\begin{array}{c}\text { I feel } \\
\text { a resident of } \\
\text { the region }\end{array}$ & $\begin{array}{l}\text { I feel } \\
\text { a citizen of } \\
\text { Poland }\end{array}$ & $\begin{array}{c}\text { I feel } \\
\text { a European }\end{array}$ & $\begin{array}{l}\text { I feel a cit- } \\
\text { izen of the } \\
\text { world }\end{array}$ \\
\hline \multirow{2}{*}{$\begin{array}{l}\text { Professional } \\
\text { prospects after } \\
\text { studies }\end{array}$} & S & & $\mathrm{H}$ & & $\mathrm{H}$ & $\mathrm{H}$ \\
\hline & NS & $\mathrm{L}$ & & $\mathrm{L}$ & & \\
\hline \multirow{2}{*}{$\begin{array}{l}\text { Economic } \\
\text { situation of } \\
\text { the state }\end{array}$} & S & $\mathrm{H}$ & & & & \\
\hline & NS & $\mathrm{L}$ & & $\mathrm{L}$ & & \\
\hline \multirow{2}{*}{$\begin{array}{l}\text { Political sit- } \\
\text { uation of the } \\
\text { state }\end{array}$} & S & $\mathrm{H}$ & & & & \\
\hline & NS & $\mathrm{L}$ & & & & \\
\hline
\end{tabular}

Legend: S - satisfaction; NS - no satisfaction; H - high significant evaluation; L - low significant evaluation

Source: authors' own research.

Two dimensions of the feeling of identity - the European and supra-European one - are determined by significantly positive evaluations resulting from students' satisfaction at their professional prospects after their studies $(Z=2.67 ; \mathrm{p}=0.008)$, friends $(\mathrm{Z}=2.32 ; \mathrm{p}=0.02)$, emotional life $(\mathrm{Z}=2.21 ; \mathrm{p}=0.03)$ and family life $(\mathrm{Z}=$ $2.01 ; \mathrm{p}=0.04)$.

Satisfaction (or its lack) due to the financial situation and their own life and educational achievements does not significantly differentiate the evaluations of all the surveyed students' feeling of identity. What draws attention in the general image of the respondents' assessment of their own life situation and satisfaction at it is the low evaluation of the feeling of being a citizen of Poland. It can be assumed that the contemporary phenomena (associated with globalization, integration or immigration) taking place worldwide are changing the way of thinking about oneself and Others. The choice of the place/country of everyday life, work or education verifies the perception of oneself and of Others and contributes to the change of the feeling of identity and the related behaviour patterns. The surveyed academic youth living in the cultural borderland shape their awareness in complex sociocultural arrangements, which in turn verify their view on and evaluation of the present reality (Ogrodzka-Mazur, Saukh, 2019).

Therefore, it can be stated that university students fulfil their own life aspirations in three basic perspectives of self-perception and the perception of the surrounding culturally diversified environment: 
- in the perspective indicated by the category of "time" - which orientates academic youth in their choices towards the present and future time, determined by the own group's traditions;

- in the perspective indicated by the category of "identity structure";

- in the perspective pertaining to the category of "social role".

\section{A portrait of Ukrainian academic youth}

Today in Ukraine the vast majority of school graduates are trying to undertake university education. In 2020, this majority is $80 \%$. However, the current Ukrainian sociological research shows that the choice of higher professional education is only partly due to interest in a particular profession. More than on a profession, young people focus on their future social status. It means that the social orientation of school graduates in Ukraine is formed before the professional one. They often have little interest in the content of the future profession, but are aware of what life benefits, privileges, well-being it provides. Obviously, this explains the fact that in recent years the number of people wishing to obtain law, economic and financial education has sharply increased. According to Ukrainian youth, these types of education provide an opportunity to be a leader in the future, a well-off person, and to have a high social rank. The modern Ukrainian student has become more pragmatic, which is manifested in the desire to get a better job in life, to achieve material well-being and high social status with the help of education.

It is "material well-being" as a terminal (life) value that ranks first in the context of the value orientations of modern Ukrainian students (Table 2). In addition, they are particularly concerned about such values as "domestic comfort", "special peace and absence of trouble", "economic" and "physical security", which can also be attributed to "materialist" values, which is obviously due to the economic crisis, corruption, inflation, and war, experienced by the Ukrainian society. Our research shows that $80 \%$ of young people believe that the current economic conditions in the country are the main cause of poverty, and only $6 \%$ of respondents believe that the current situation in the country allows one to ensure the well-being by personal labor.

Ukrainian students are most concerned about such things as corruption (37\%) and war (36\%). These fears dominate in all regions of Ukraine. At the same time, students are concerned about unemployment (32\%), and their fear is the biggest in Kyiv and the Eastern part of Ukraine (39\%). 
Table 2. The orientation of Ukrainian students to terminal (life) values

\begin{tabular}{|c|c|c|c|}
\hline № & Value orientations & $\%$ & Rank \\
\hline 1 & Education, knowledge & 46.8 & 5 \\
\hline 2 & Interesting, creative work & 28.8 & 10 \\
\hline 3 & Material well-being & 66.5 & 1 \\
\hline 4 & Opportunity to bring benefits to people & 8.2 & 18 \\
\hline 5 & Family & 48.2 & 3 \\
\hline 6 & Health & 47 & 4 \\
\hline 7 & $\begin{array}{l}\text { Personal freedom, independence in } \\
\text { judgments and ideas }\end{array}$ & 36.6 & 8 \\
\hline 8 & Domestic comfort & 35.6 & 9 \\
\hline 9 & Respect for others & 15.1 & 14 \\
\hline 10 & Dignity & 57.2 & 2 \\
\hline 11 & Moral stability & 40 & 7 \\
\hline 12 & Honesty & 10 & 16 \\
\hline 13 & $\begin{array}{l}\text { Participation in public life, in solving } \\
\text { social problems }\end{array}$ & 23.2 & 12 \\
\hline 14 & Ecological safety & 7.2 & 19 \\
\hline 15 & $\begin{array}{l}\text { Opportunity to develop, use their } \\
\text { abilities }\end{array}$ & 9 & 17 \\
\hline 16 & $\begin{array}{l}\text { Understanding relationships with par- } \\
\text { ents, the older generation }\end{array}$ & 18.6 & 13 \\
\hline 17 & Complete rest, entertainment & 26.5 & 11 \\
\hline 18 & Economic independence & 40.1 & 6 \\
\hline 19 & High official and social position & 12.3 & 15 \\
\hline 20 & Involvement in literature and art & 5.6 & 20 \\
\hline
\end{tabular}

Source: authors' own research

It is also significant that in addition to material well-being, the first places are held by "family" (48.2\%) and "health" (47\%) and this is understandable, because these axiophenomena are the foundation of human well-being. However, the "health" of the student environment is not a simple issue. Physicians determine health disorders in $90 \%$ of students, more than half of whom have an unsatisfactory physical condition. Students themselves are much more optimistic about their own health. According to our sociological research, $42.7 \%$ of respondents consider it good, $39.9 \%$ do not consider it very good, and $16.6 \%$ of respondents assess their health as satisfactory. 
It is also important in the university environment that the percentage of students who have the so-called "distorted motivation" is quite small (28\%). The survey shows that $51 \%$, when choosing a profession, is guided by the opportunity to get a good job, and 50\% - to acquire professional knowledge and skills. The question whether students would like to engage in research activities after higher education is answered "no" by $69 \%$ and "yes" by $31 \%$. Interestingly, the motivation for higher education differs between those who see their future in science and

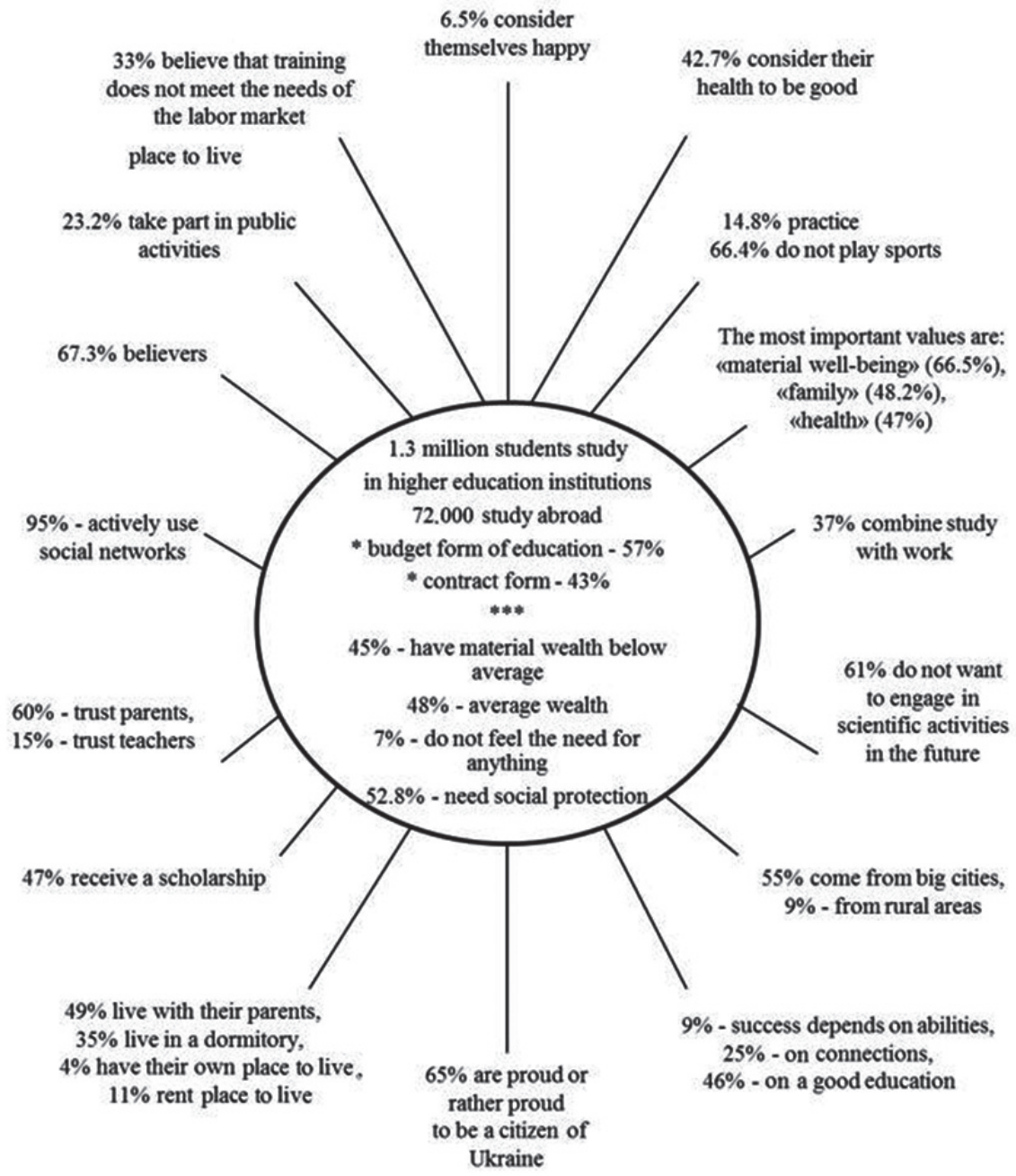

Figure 1. A portrait of Ukrainian academic youth 
those who do not. Among "potential scientists", $45 \%$ entered the university for personal intellectual development, $57 \%$ - for professional skills and only $22 \%$ indicated obtaining a diploma as a reason. The relevant indicators for those who do not want to go into science $-35 \%, 47 \%$ and $36 \%$. The motivation for a future job also differs. Work in the specialty is important for $67 \%$ of those who are ready to engage in scientific activities in the future, compared to $55 \%$ of those who are not ready. Instead, the salary is also less important for them - $73 \%$ vs. $80 \%$.

The attitude of Ukrainian students to such life values as "participation in public life, in solving social problems" (23.2\%), "opportunity to bring benefits to people" (8.2\%), "environmental safety" (7.2) is of some concern. "Involvement in literature and art" (5.6\%), in our opinion, requires increased attention to education and communicative competence of future members of the Ukrainian intellectual elite. The analysis of these issues in terms of gender shows that girls are three times more actively involved in public activities, more actively concerned about environmental safety, literature and art. The sociological research shows a positive attitude of university youth to religion. Only $32.7 \%$ consider themselves non-believers and $67.3 \%$ believers, although they state that they do not belong to any particular denomination.

Ukrainian students value the most: decency (59.5\%), self-esteem (57.2\%), understanding (44.1\%), independence $(41.6 \%)$, freedom $(36.6 \%)$, and do not tolerate: betrayal (80.9\%), cruelty (49.2\%), greed (33.8\%) and ignorance $(23.1 \%)$. Yet, the most important thing in the university student environment of Ukraine is that there is a confusion about the future (35.5\%) and only $6.5 \%$ of students consider themselves happy.

Thus, the study has helped to construct a "portrait of Ukrainian university youth", namely to allow a comprehensive view of the social feelings and values of students, their activity in various spheres of society (Figure 1). The portrait is not stable, and in time, it depends on many factors, such as economic stability, educational reforms, some new elevating factors in the society, etc.

\section{Conclusions}

In the present conditions, the characteristic features of students both in Poland and Ukraine stand out significantly from other segments of the population. This has also a special role in the youth environment. Compared to other groups of young people, students can be distinguished by the following features: higher education; a strong desire for knowledge; high social activity; quite a harmonious 
combination of intellectual and social maturity. As an integral part of youth, university students are a specific social group of different social statuses and characterized by specific working and living conditions, social behavior and mentality, and a system of values, for which the acquisition of knowledge and training for work in social production, science and culture is the main or mostly the main occupation. Students are a potential elite of the society, an intellectual source of the nation.

However, as a special social group of transitional (essentially marginal) nature, students have rather an unstable culture and act as a focus group for future society as a whole. This group is characterized by a certain kind of "border", which makes it an extremely mobile part of society, sensitive to any changes in its structure, quickly capturing new trends in culture (Saukh, 2019, pp. 67-70). It is more efficient than other segments of the youth, reacts quickly to new trends in rapidly changing technologies, business environment, fashion, literature, music, etc. As a specific sociocultural community, university students are characterized by: (1) the temporality of their social status; (2) the intensity and scale of communication; (3) lack of life and social experience, variability of behaviors, and at the same time, curiosity, the desire to expand knowledge, a polarized vision of problems and the attempts to solve them in the most radical way; (4) maximalism, often an exaggerated assessment of one's own opinion, a certain confrontation with the older generation.

At the same time, students most vividly generate and present some new ideas and advanced views. In any time and geographical space, academic youth forms an innovative reserve of the reformist section of the society, acting as a testing ground for the production of progressive forces of society, unfortunately - often becoming a hostage of destructive forces.

Therefore, the methodological matrix of the parameters applied in the portrait of students in Poland and Ukraine is as similar as possible. This is explained, firstly, by the fact that Polish and Ukrainian students are not homogeneous groups. They have different social backgrounds and the economic, cultural and social capital. Secondly, despite their internal differentiation, students are a sociocultural community that has a similar lifestyle, specific behaviour patterns and values. Thirdly, as a social group, students are in a certain border zone between a passive object of the state and social care and an active subject of social action. Fourthly, academic youth is characterized by rational and pragmatic thinking and understanding that success in life depends only on them. This means that students have a positive desire for self-fulfilment through the use of their own intellectual potential. Fifthly, despite the lack of "commitment to common ideals" and "national snobbery" in the 
student community, it is characterized by both patriotism and cosmopolitanism. Migration processes, which take place both among Polish and Ukrainian students, are rather related to dissatisfaction with their place in society and the attitude of political powers to their role in the socio-economic and cultural life of the society. Sixthly, students are a flexible and dynamic social group as regards changing basic values, they are a source of critical reflection upon the experience of previous generations, they have significant innovative potential and a high susceptibility to innovation and risk-taking. Seventhly, the academic youth has a balanced or critical attitude to various negative phenomena, which, according to its representatives, are quite common among young people - consumerism, ignorance, intolerance, cruelty and violence.

However, the portrait of Polish and Ukrainian students has its own characteristics, due to e.g. national traditions, different living standards, and the attitude of the authorities to the problems of youth. In this discourse, it is the youth environment, represented by students, that serves as the laboratory which produces and tests previously unknown values, attitudes, patterns of behavior, cultural norms and patterns.

\section{References}

Arnett, J.J. (2000). Emerging adulthood. A theory of development from the late teens through the twenties. American Psychologist, 55 (5), 470-479.

Boski, P. (2009). Kulturowe ramy zachowań społecznych. Podręcznik psychologii międzykulturowej [Cultural framework of social behavior. Handbook of intercultural psychology]. Warszawa: PWN.

Bruner, J.S. (1996). The culture of education. Cambridge: London Harvard University Press. European Commission/EACEA/Eurydice. (2018). The European Higher Education Area in 2018: Bologna Process Implementation Report. Luxembourg: Publications Office of the European Union.

Laird, M.D., Harvey, P., \& Lancaster, J. (2015). Accountability, entitlement, tenure, and satisfaction in Generation Y. Journal of Managerial Psychology, 30 (1), 87-100.

Lunenburg, F.C. (1998). Constructivism and technology: instructional designs for successful education reform. Journal of Instructional Psychology, 25 (2), 75-81.

Malinauskas, R., Dumciene, A., \& Lapeniene, D. (2014). Social skills and life satisfaction of Lithuanian first- and senior-year university students. Social Behavior and Personality, 42 (2), 285-293.

Marshall, J. (2014). Introduction to comparative and international education. Los Angeles London - New Delhi - Singapore - Washington: Sage Publications Ltd.

Noah, H.J., \& Eckstein, M.A. (1988). Dependency theory in comparative education: twelve 
lessons from the literature. In: J. Schriewer, B. Holmes (eds), Theories and methods in comparative education. Frankfurt am Main: Peter Lang Publishers, 165-192.

Ogrodzka-Mazur, E., \& Saukh, P. (2019). The social and cultural tendencies in the environment of contemporary youth. A Polish-Ukrainian comparative study of the structure of axiological reality. The New Educational Review, 57 (3), 63-74.

Report to the European Commission on New modes of learning and teaching in higher education (2014). Luxembourg: Publications Office of the European Union.

Riberio, I.J.S, Pereira, R, Freire, I.V., Oliveira, B.G., Casotii, C.A., \& Boery, E.N. (2018). Stress and quality of life among university students: a systematic literature review. Health Professions Education, 4, 70-77.

Saukh, P. (2019). Characteristics of the new "Z" - walk and features work with him in the context of the New Ukrainian School. In: Practical philosophy and the New Ukrainian School: a collection of theses of the all-Ukrainian scientific and practical conference. Kiev: National Academy of Pedagogical Sciences of Ukraine, 66-70. 